\title{
An Assessment of Decision to Change Lifestyle in Cardiovascular Patients after Hospitalization
}

1 Anita Makar

2 Zrinka Pukljak Iričanin

3 Jadranka Pavić

1 Kindergarten „Osmijeh“, Sveta Nedelja, Croatia

2 Department of Health Psychology, University of Applied Health Sciences, Zagreb, Croatia

3 Department of Nursing, University of Applied Health Sciences, Zagreb, Croatia

Article received: 29.10.2018.

Article accepted: 30.01.2019.

DOI: $10.24141 / 2 / 3 / 1 / 2$

Author for correspondence:

Zrinka Pukljak Iričanin

University of Applied Health Sciences

Mlinarska cesta 38, Zagreb, Croatia

Phone: +38515495924

E-mail: zrinka.pukljak-iricanin@zvu.hr

Keywords: lifestyle, cardiovascular diseases, change decision, prevention

\section{Abstract}

The aim of this study was to examine the lifestyle of cardiovascular patients with different diagnoses, as well as the willingness to change lifestyle after hospitalization. These results can significantly influence everyday nursing practice during rehabilitation and education of cardiovascular patients and increase motivation to change risk behavior. The participants of the study were the patients at the Cardiology Department of the Special Hospital for Medical Rehabilitation Krapinske Toplice ( $\mathrm{N}=70)$. In assessing their lifestyle before the hospitalization most participants agreed with the statements "I was often tense, angry or concerned about the events in the society" and "I was often tense, angry or worried while following the media". Rural participants compared to those from urban areas estimated their lifestyle before hospitalization statistically as more risky. Most participants decided to change their lifestyle compared to the habits they had before hospitalization. They mostly agree with the statements related to the decision of reducing cigarette consumption and walking more. Older participants brought significantIy less decisions of changing lifestyle after hospitalization. Furthermore, there were no significant differences in the decision to change lifestyle in terms of gender, work activity and professional occupation. Participants with arrhythmia had a statistically significant higher value of lifestyle change compared to those who had myocardial infarction and hypertension. Participants with bypass had a statistically significant higher value of decision to change lifestyle compared to those who were hospitalized because of arrhythmia. These results are useful for identifying groups of patients where nurses need to make additional efforts to encourage motivation to change risky lifestyle. 


\section{Introduction}

Chronic non-communicable diseases are responsible for $93 \%$ of mortality in Croatia (1). Among them, the leading cause of mortality and stroke are cardiovascular diseases (CVD). In 2017, 23504 people died of the latter which makes $44 \%$ of total deaths. Ischemic heart disease has the largest share in total mortality with $20.7 \%$ (11069) and cerebrovascular disease with $11.5 \%$ (6147) (2). It is the same case with the leading causes of mortality on an average global level (3), although since recently in some Western European countries the leading cause of mortality have been malignant diseases (4). Since the mid-20th century, there has been an undeniable correlation of the risk of illness from non-communicabe chronic diseases and lifestyle, or characteristics of health behavior. Since then, there is a great interest in identifying the factors which determine one's health behavior. The aim is to find out which factors can affect the learning of protective health behavior and the prevention, postponement or alteration of risky health behaviors. Nowadays, it has been found that the interdependence and correlation of the factors of health behavior is quite complex (5). Therefore, a number of theories or patterns of health behavior have emerged, which differ in terms of what psychosocial factors are considered to be key in achieving the desired behavior. But there is a common assumption that human behavior is essentially rational and deliberate, and that people decide to change or adopt new behaviors after making a decision on a complex process (6). Making the decision to change is the first step towards a real change in behavior and all the knowledge about the factors that influence decision-making are significant to the work of health professionals, especially nurses during the rehabilitation of cardiovascular patients.

Lifestyle, as a manifestation of a series of individual behaviors, partially depends on internal, psychological factors, or serves as a form of self-expression of values and attitudes of an individual (3). On the other hand, it is influenced by external geographic, demographic, economic and social factors. The social environment acts as a model and measure for comparing and evaluating one's own behavior and makes different lifestyles available to the individual. Risk factors can be divided into: risk factors that cannot be influenced ("invariable risk factors") which include age, gender, genetic inheritance, race and risk factors, and those which can be affected ("variable risk factors") such as stress, depression, smoking, inadequate physical activity, obesity, alcohol, unhealthy diet. In the Maćešić and Špehar research (2013), cardiovascular risk of 150 patients over the age of 40 was estimated at the general practitioner's. The results show that general practitioners are mostly visited by patients aged from 60 to 69 years old. There are more women aged between 50 and 59 which is related to menopause (7). $43 \%$ of patients are overweight, $35 \%$ are obese. The highest number of women and men have normal blood pressure as a result of regular therapy (71\%). $16 \%$ of participants have regular exercise, $21 \%$ of respondents consume alcohol, and a small percentage of respondents smoke (7). Patients were much more receptive to taking regular therapy than to the need for a change in lifestyle, in this case physical activity and nutrition.

According to studies in different populations, the most significant (44-76\%) prevention and risk behavioral change is associated with the reduction of mortality from cardiovascular disease, and $23-47 \%$ reduction is attributed to therapeutic interventions (8). In favour of these studies are also the results of multi-year preventive activities in Western Europe and North America where there is a reduction in the incidence of cardiovascular disease.

Preventive activities include primary and secondary prevention, population and individual approach. Primary prevention focuses on lifestyle education (non-smoking, physical activity, proper nutrition) and avoidance of risk. It starts from the earliest age, in kindergarten and school where children are taught about health and healthy lifestyles. Secondary prevention is aimed at preventing the deterioration of the disease, the occurrence of complications in rehabilitation, reduction of disability and the preservation of life quality in patients which have already developed an illness. Population approach interventions are directed towards the population with low or medium risk and individual access to high risk individuals. Both approaches are commonly implemented. Population approaches to prevention include changing lifestyle change, social and economic determinants, and they must be an integral part of public policy and involve other sectors of society (9). Prevention plays an important, crucial role and is a problem that needs to be systematically addressed by health policy, with 
the emphasis on strengthening individual's personal responsibility in the field of lifestyle choices (10). The promotion of healthy lifestyles has to be spread locally as much as possible, providing common availability of the abovementioned activities.

An example of good practice is the healthcare reform in the Netherlands. It started by the adoption of the National Preventive Plan in 2014, which advocates promoting health and disease prevention in the areas where people live, work, and learn. Prevention is given an important role in the health care of cardiovascular diseases and cardiovascular disease has fallen to the second place as the cause of mortality, behind malignant diseases (4).

According to our findings, a clinical study studying the lifestyle of cardiovascular patients before hospitalization, as well as the decisions of changing lifestyle or different health behaviors after hospitalization has not been conducted in Croatia. Such research could be of great importance to nurses and other health workers during the rehabilitation and education of cardiovascular patients.

Therefore, the aim of our research regarding hospitalized patients with cardiovascular diseases was to:

1. Identify common health behavior

2. Determine the decision-degree of changing health behavior after hospitalization

3. to examine the differences in health behavior before hospitalization and decisions to change health behavior after hospitalization due to the reason of hospitalization, age, sex and the environment in which patients live.

The underlying hypothesis is that there are different lifestyles and different degrees of willingness to change behavior after hospitalization among the patients with different diagnosis and different sociodemographic characteristics.

\section{Methods}

The participants in the study were patients $(\mathrm{N}=70)$ at the Cardiology Department of the Special Hospital for Medical Rehabilitation Krapinske Toplice, 38
(54.3\%) men and 32 (45.7\%) women. The age range was from 31 to 83 years, with an average value of 61.37 (SD = 12.209). Most participants $(41.4 \%)$ had completed secondary school, $22.9 \%$ had a bachelor degree, $20.0 \%$ finished primary school and $15.7 \%$ participants had a master's degree. Most participants (64.3\%) didn't work. Most of the participants (47.1\%) lived in a city, $30 \%$ in a village and $22.9 \%$ in a suburban area. The most common cause of hospitalization was myocardial infarction (Table 1 ).

\begin{tabular}{|ccc|}
\hline $\begin{array}{c}\text { Table 1. Reasons for participants' } \\
\text { hospitalization }\end{array}$ \\
\hline Reason for hospitalization & N & $\%$ \\
\hline Angina pectoris & 12 & 17.1 \\
\hline Arrhythmia & 4 & 5.7 \\
\hline Hypertension & 12 & 17.1 \\
\hline Myocardial infarction & 35 & 50 \\
\hline Bypass & 7 & 10 \\
\hline & 70 & 100 \\
\hline
\end{tabular}

\section{Materials and procedure}

The research was conducted in July 2017 with a questionnaire compiled for this purpose. The questionnaire contained socio-demographic data, the reason for hospitalization, 17 statements about lifestyle before hospitalization and 17 statements related to the decision of changing lifestyle after hospitalization. With each statement, the participants chose one of the answers: (1) completely disagree, (2) partially agree or (3) fully agree. The overall score for assessing lifestyle before hospitalization as well as the overall outcome of the decision to change lifestyle after hospitalization was obtained by summing up the estimates on individual claims. 80 questionnaires were distributed and 70 which were properly filled out were statistically analyzed. The research was voluntary, anonymous and approved by the Ethical Committee of the Special Hospital for Medical Rehabilitation Krapinske Toplice. Data were analyzed using SPSS 17.0. 


\section{Results}

In the analysis of lifestyle prior to hospitalization, the highest average response was: "I was often tense, angry or concerned due to social events" ( $M=2.06)$ and "I was often tense, angry or worried while following the media " $(M=2.06)$. The lowest average response was: "Daily consumed more alcoholic beverages" ( $M=1.47)$ and "Daily consumed more than one packet of cigarettes " ( $M=1.50)$ (Table 2).

\begin{tabular}{|c|c|c|}
\hline Before hospitalization I: & M & SD \\
\hline $\begin{array}{c}\text { was often tense, angry or worried due to } \\
\text { social events }\end{array}$ & 2.06 & 0.72 \\
\hline $\begin{array}{l}\text { was often tense, angry or worried while } \\
\text { following the media }\end{array}$ & 2.06 & 0.74 \\
\hline $\begin{array}{l}\text { didn't regularly control my health } \\
\text { condition }\end{array}$ & 2.01 & 0.7 \\
\hline $\begin{array}{c}\text { was often stressed because of financial } \\
\text { problems }\end{array}$ & 2.00 & 0.80 \\
\hline rarely or never walked & 1.93 & 0.69 \\
\hline didn't indulge in any & 1.89 & 0.67 \\
\hline didn't regularly take prescribed medicine & 1.81 & 0.71 \\
\hline ate a lot of processed meat & 1.73 & 0.66 \\
\hline $\begin{array}{c}\text { was often under pressure due to work } \\
\text { situation }\end{array}$ & 1.73 & 0.70 \\
\hline ate a lot of salty food & 1.70 & 0.66 \\
\hline had irregular meals & 1.69 & 0.79 \\
\hline ate mostly fatty food & 1.67 & 0.70 \\
\hline consumed a lot of candy & 1.60 & 0.71 \\
\hline daily consumed one packet of cigarette & 1.60 & 0.81 \\
\hline $\begin{array}{c}\text { daily consumed sparkling and sweetened } \\
\text { beverages }\end{array}$ & 1.54 & 0.70 \\
\hline $\begin{array}{l}\text { daily consumed more than one packet of } \\
\text { cigarette }\end{array}$ & 1.50 & 0.74 \\
\hline daily consumed more alcoholic beverages & 1.47 & 0.68 \\
\hline \multicolumn{3}{|l|}{ mean, SD - sta } \\
\hline
\end{tabular}

In the analysis of the responses about the decision to change lifestyle after hospitalization, the most common response was "I decided to reduce cigarette consumption" ( $M=2.66)$ and "I decided to walk more often" (M=2.64). The lowest response rate was achieved with the statement "I decided to have regular meals" ( $M=2.40)$ and "I decided not to stress about the social events" $(M=2.44)$.

\section{Table 3. Descriptive indicators for assessment} of changes in lifestyle after hospitalization

After hospitalization I decided: $\quad$ M SD

to reduce the consumption of cigarettes $2.66 \quad 0.54$

$\begin{array}{lll}\text { to walk more often } & 2.64 & 0.48\end{array}$

not to consume cigarettes $\quad 2.61 \quad 0.55$

not to consume alcohol $\quad 2.61 \quad 0.49$

to regularly took prescribed medicine $\begin{array}{lll}2.60 & 0.49\end{array}$

not to stress about work situation $\quad 2.59 \quad 0.50$

not to eat fatty food $\quad 2.59 \quad 0.52$

to reduce salt in food $\quad 2.59 \quad 0.52$

to reduce consumption of candies $\quad 2.56 \quad 0.50$

to do more physical activity $\quad 2.51 \quad 0.58$

$\begin{array}{lll}\text { to regularly control health condition } & 2.51 & 0.61\end{array}$

not to consume sparkling and sweetened $2.49 \quad 0.56$ beverages

not to stress about the media content $\begin{array}{lll}2.47 & 0.63\end{array}$

$\begin{array}{lll}\text { not to eat processed meat } \quad 2.47 & 0.58\end{array}$

not to stress about financial situation $\begin{array}{lll}2.46 & 0.61\end{array}$

not to stress about social events $\quad \begin{array}{lll}2.44 & 0.61\end{array}$

to have regular meals $\quad 2.40 \quad 0.62$

Legend: M - arithmetic mean, SD - standard deviation

In order to determine the differences in the assessment of the lifestyle prior to the decision of changing lifestyle after hospitalization according to the sociodemographic characteristics of participants, we used nonparametric procedures because all distributions of results deviate from normal.

There are no statistically significant differences in the lifestyle assessment before and decision to change the lifestyle after hospitalization due to the gender and work activity of participants.

There is a statistically significant correlation between the age of the participants and the decision level of change in the lifestyle after hospitalization $(r=-0.340, p<0.01)$. Older participants make significantly less decisions about lifestyle changes after hospitalization due to cardiovascular disorders.

Due to qualifications of the participants, there are no statistically significant differences in the estima- 


\begin{tabular}{lcccccccc}
\multicolumn{7}{l}{ Table 4. Comparison of lifestyle and decision about changing lifestyle considering gender and work } \\
activity
\end{tabular}

\begin{tabular}{|c|c|c|c|c|}
\hline & & Age & $\begin{array}{l}\text { Lifestyle before } \\
\text { hospitalization }\end{array}$ & $\begin{array}{c}\text { Decision to change after } \\
\text { hospitalization }\end{array}$ \\
\hline \multirow{2}{*}{ Age } & $\mathrm{R}$ & 1 & .040 & $-.340^{* *}$ \\
\hline & $p$ & & .740 & .004 \\
\hline \multirow{2}{*}{ Lifestyle before hospitalization } & $\mathrm{R}$ & .040 & 1 & -.203 \\
\hline & $P$ & & & .092 \\
\hline \multirow{2}{*}{$\begin{array}{l}\text { Decision to change after } \\
\text { hospitalization }\end{array}$} & $\mathrm{R}$ & & -.203 & 1 \\
\hline & $p$ & $-.340^{* *}$ & .092 & \\
\hline
\end{tabular}

Table 6. Comparison of lifestyle and decision about changing lifestyle considering qualifications

\begin{tabular}{|ccccccc} 
& Qualifications & H & P & P \\
\hline $\begin{array}{c}\text { Elementary } \\
\text { education }\end{array}$ & $\begin{array}{c}\text { Secondary } \\
\text { education }\end{array}$ & $\begin{array}{c}\text { Two-year } \\
\text { degree }\end{array}$ & $\begin{array}{c}\text { University } \\
\text { education }\end{array}$ & & & \\
\hline $\begin{array}{c}\text { Lifestyle before } \\
\text { hospitalization }\end{array}$ & 14 & 29 & 16 & 11 & 6.186 & 0.103 \\
\hline $\begin{array}{c}\text { Decision to change after } \\
\text { hospitalization }\end{array}$ & 13 & 29 & 16 & 11 & 2.838 & 0.417 \\
\hline
\end{tabular}

\section{Table 7. Comparison of lifestyle and decision about changing lifestyle considering place of} residence (Kruskal Wallis test)

\begin{tabular}{ccccccc} 
& $\mathrm{N}$ & $\mathrm{N}$ & $\mathrm{N}$ & H & P \\
& Village & City & Suburban area & & \\
\hline Lifestyle before hospitalization & 21 & 33 & 16 & 6.842 & 0.033 \\
\hline Decision to change after hospitalization & 21 & 33 & 16 & 2.520 & 0.284 \\
\hline
\end{tabular}

tion of lifestyle before (Kruskal Wallis $\mathrm{H}=6.186, \mathrm{df}=3$, $p>0.05)$ and the decision to change the lifestyle after hospitalization (Kruskal Wallis $\mathrm{H}=2.838$, $\mathrm{df}=3$, p>0.05).

There is a statistically significant difference in the overall estimation of lifestyle before hospitalization regarding the environment in which the partici- pants live (Kruskal Wallis $\mathrm{H}=6.842, p=0.033$ ). Rank Sum Tests were conducted in order to compare the groups and to determine between which groups and in which direction there was a difference.

Participants from the countryside compared to urban population estimate their lifestyle as more risky (Mann-Whitney $U=198.5, p<0.01$ ). 


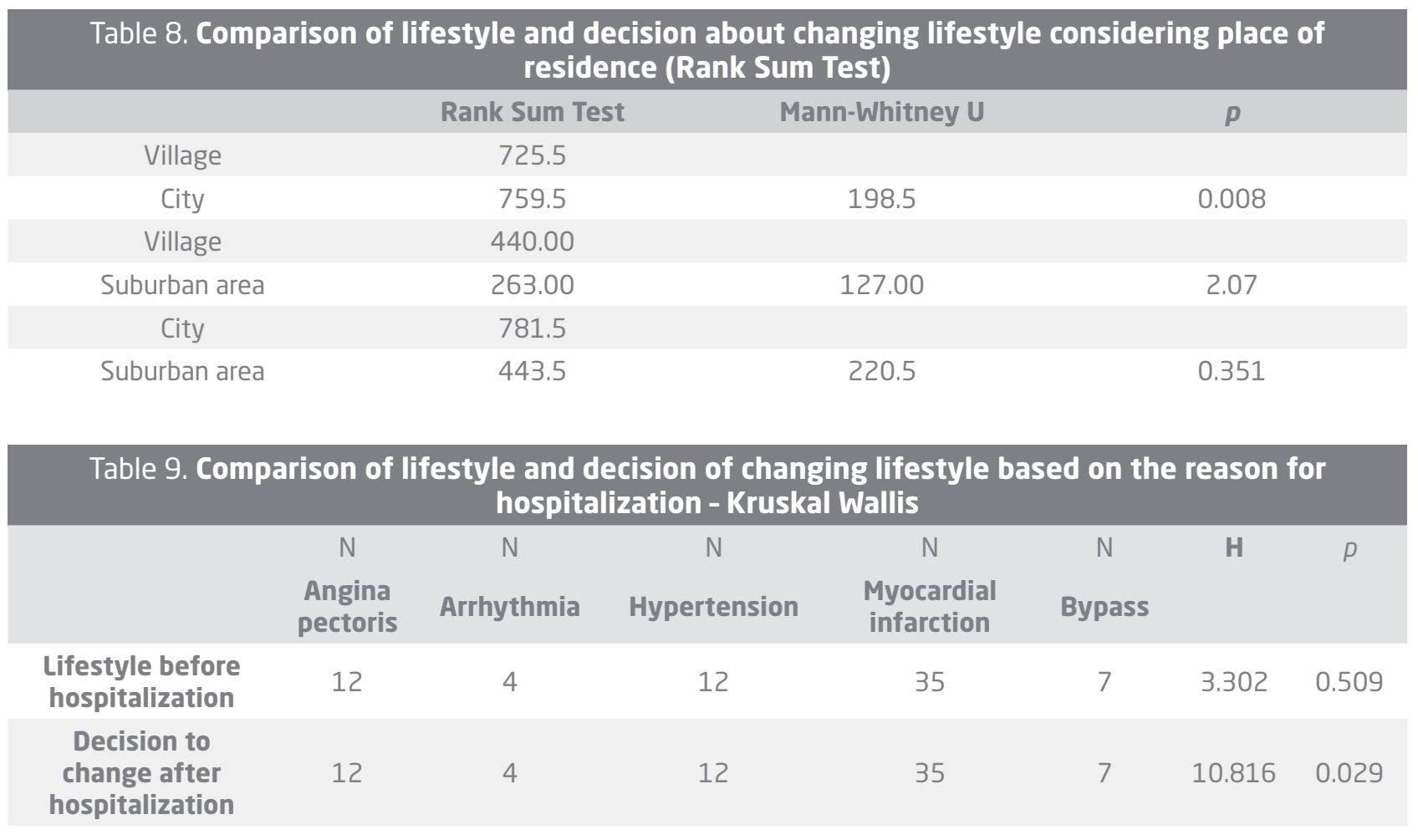

There is a statistically significant difference in the decision-making rate of lifestyle after hospitalization due to the reasons of hospitalization of the respondent (Kruskal Wallis $\mathrm{H}=10.816, p<0.05$ ). Rank Sum Tests were conducted to compare the differences among groups.

In three cases, differences were statistically significant. Respondents hospitalized for arrhythmia (sum of ranks=126.5) compared with those with myocardial infarction (sum of ranks $=653.50$ ) have a statistically significant higher degree of the decision to change (Mann Whitney $\mathrm{U}=23.5, p=0.031$ ). Respondents hospitalized for arrhythmia (sum of ranks $=54.50$ ) had a statistically significant higher degree of change in lifestyles (Mann Whitney $U=3.5$, $p=0.013$ ) compared with hypertensive subjects (sum of ranks=81.50). Respondents hospitalized for bypass (sum of ranks $=28.00$ ) compared to those hospitalized for arrhythmia (sum of ranks=38.00) had a statistically significant higher level of decision on lifestyle (Mann Whitney $\mathrm{U}=0.00, p=0.008$ ).

\section{Discussion}

There are numerous scientific evidence on the impact of lifestyle (eating habits, cigarettes and alcohol consumption, physical activity level, regular medical examinations, etc.) on health. For people with a dominant negative health behavior, among other things, the risk of cardiovascular disorders and illnesses is much higher. Therefore, in this study, we were interested in evaluating the lifestyle of patients with already confirmed cardiovascular disorders who were hospitalized at the rehabilitation department for cardiac patients.

In assessing the lifestyle before hospitalization, the highest degree of agreement occured with the statements "I was often tense, angry or worried about the events in society" and "I was often tense, angry or worried while following the media". These findings can be seen in the context of numerous studies in which psychosocial risk factors for cardiovascular disease development have shown that people who tend to experience negative affective states and poor mood are generally prone to develop cardiovascular disease $(8,9,11,12)$. Negative emotions act as stressors. Exposure to stressors triggers epineph- 
rine, norepinephrine and other stress hormones, accelerated heartbeat and significant changes in the blood pressure (13). Repeated stressors constantly stimulate cardiac activity. It comes to the straining and tiredness of the cardiovascular system - this leads to permanent constriction of small peripheral arteries which results in elevated blood pressure. Thus, elevated blood pressure acts on the coronary artery, and in the presence of other risk factors the probability of heart attack increases.

The tendency towards negative emotional experience increases the risk of developing depression. Depression is a psychological factor that mostly affects the recovery of patients with survived myocardial infarction and other cardiovascular diseases. It is estimated that more than $30 \%$ of patients after myocardial infarction have a clinical picture of depression (14). Depression is a predictor of the risk of re-coronary incidence and total mortality of cardiovascular patients. Depression is more pronounced in older patients with myocardial infarction (13). Findings on the impact of certain characteristics and dependence of patients' emotional experience on probability of cardiovascular incidents emphasize the importance of biopsychosocial access to the patient and the assessment and appreciation of individual differences as factors can contribute to the development and course of the disease itself. The role of nurses who actively participate in the rehabilitation of patients after cardiovascular incident and prevention is of paramount importance.

As part of the second problem, our research has examined the willingness of patients to change their negative health behavior and the degree of change in decision after hospitalization. Assessment of the decision, or showing intention of change, is a significant factor in numerous research $(10,15-18)$.

In assessing the willingness to change their lifestyle, most patients have decided and are ready to change their lifestyle or health behaviors with regard to what they had before the hospitalization. All the average values reffering to estimation decisions of change are in between (2) "I partially agree", and (3) "I fully agree" (Table 3).

The highest average response was obtained for the following statements "reduce cigarette consumption" and "walk more", suggesting that there is significant awareness of cigarette consumption and inadequate physical activity and most individuals are ready for change.
Smoking promotes and initiates the process of atherosclerosis during which plaques (the accumulation of fat, binder and calcium) occur in the blood vessels. Such narrowing of the blood vessels creates inadequate blood flow to the individual parts of the heart and brain, and may also end with death due to stroke or heart attack. Smoking increases the level of fibrin (blood coagulation factor) that is "absorbed" by plaques and thus further narrows blood vessels, causes increased blood pressure, increased oxygen consumption, minute volume increase, increased platelet aggregation, increased glucose in blood, cortisol, vasopressin and beta endorphin (19). The most common consequence of smoking that occurs in the bloodstream is coronary heart disease. Smoking leads to a drop in the flow through the coronary artery which, with the change of resistance, leads to myocardial ischemia.

The risk of developing cardiovascular and other chronic diseases increases with the number of smoked cigarettes, smoking age, smoking habits and the degree of smoke inhalation. A particular problem is tobacco smoking as a cause of premature mortality in younger population, which implies the loss of potentially active years of life. Permanent smokers are twice as likely to develop cardiovascular disease (one half of the smokers die of cardiovascular disease), and their risk of sudden death is three times greater (20). The risk of cardiovascular disease decreases with smokers who abstain from smoking for only one year. In 500000 people who die annually in the United States from cardiovascular disease, about $21 \%$ of deaths are directly related to smoking (20). Patients who get over myocardial infarction and who continue smoking have higher heart failure mortality than non-smokers, and sudden cardiac death is two to three times more common.

The high degree of adherence to a decision to walk more shows an awareness of the importance of physical activity after hospitalization. Inactive persons are twice as more susceptible to cardiovascular diseases than people involved in some physical activity (21). Only $7.6 \%$ of the population takes part in a physical activity to a degree that is sufficient to maintain their heart, circulation and lungs in good condition (3).

Regular physical activity is an immediate and independent protective factor for cardiovascular diseases, it reduces the risk of illness. Even the slightest changes in lifestyle with moderate physical activity 
in middle age reduce mortality from cardiovascular disease. People who had acute myocardial infarction, and then included in the exercise program, have a reduced mortality rate of $20-25 \%$ (22). Physical activity has a protective effect because it prevents excess weight, reduces blood pressure, improves lipoprotein status, decreases triglyceride levels and LDL cholesterol, raises the condition (15). The most recommended activities are walking, hiking, swimming and jogging.

As part of the third problem, we examined the differences in lifestyle before and after the decision to change lifestyle after hospitalization with regards to the socio-demographic characteristics of the participants (age, gender, qualification, work activity, the environment in which they live) and the reason for hospitalization. For the lifestyle prior to hospitalization, a statistically significant difference was obtained only in the area where the participants live. The highest average response was for those who lived in the countryside, respectively in the area with poor living habits before hospitalization. These results are consistent with other studies of cardiovascular disease. According to a survey of the Public Health Institute of Varaždin (22), the general mortality rate is higher in rural areas, and the main cause of death is circulatory disease (most commonly heart attack and stroke). Although nutrient-rich food is more common in rural areas, cleaner environment and lifestyle which provides more physical activity, social, cultural, sports-recreational and other amenities that affect the quality of life and individual health are more accessible in the city. Also, health care is of higher quality, especially emergency medical aid, and specialized counseling and health care are more accessible. In rural areas, there is in general worse preventative activities coverage, poor health prosperity, and greater mortality from different illnesses. Health awareness information is gained from people who had been treated for their disease prior to their death. The number of such people is up to $5 \%$ lower in rural areas than in the city, which means that a greater number of diseases remain undetected (22). Differences in the higher level of risk factors for cardiovascular disease in rural areas compared to urban environments are also gained in other social enviroments and are recognized as a global trend $(23,24)$. The age of respondents is significantly correlated with the degree of decision about changing lifestyle after hospitalization. Older respondents make signifi- cantly less decisions of lifestyle changes after hospitalization due to cardiovascular disorders, as in other similar studies $(25,26,27)$

In assessing the decision on changing lifestyles after hospitalization, there was a significant difference in the reason for hospitalization of cardiovascular patients. The decision to change is most expressed in patients with arrhythmias and angina pectoris. We can assume that this is the result of patients thinking it is a serious and potentially life-threatening condition. In accordance with the latter mentioned, further research is needed.

This results are important because of a significant role of nurses in health promotion and rehabilitation of cardiac patients. Cardiac rehabilitation leads to improvements in overall results after acute treatment through patient training by constant repetition and emphasizing the importance of regular control and healthy living habits, thus it reduces the number of recurrent hospitalizations and treatment costs (26). Our research has shown that patients are most willing to change the habits associated with smoking and physical activity, therefore nurses' role is to additionally emphasize the importance of other changes related to nutrition, alcohol consumption, regular therapy, and so on. According to the World Health Organization, three-quarters of all deaths caused by cardiovascular disease can be prevented by changing poor living habits. Successfully implemented preventive, diagnostic, therapeutic and rehabilitative measures bring a significant increase in survival and improve the quality of life, reducing the overall social and economic burden. The effectiveness of these measures is most influenced by the motivation that nurses can encourage during the nursing care of a cardiovascular patient. By promoting health, they can transfer knowledge about the importance of health, but also influence motivation for change and maintenance. Health promotion has evolved in response to increased motivation to take control of one's own life and health, limited results of "traditional" health measures and interventions, and in response to the fact that many health problems such as cardiovascular disease appear due to lifestyle and the habit of an individual (28). In the following research it would be good to examine the lifestyle of the patients even after the hospitalization itself and to determine the extent to which the decision to change the lifestyle has really affected the health behavior of cardiac patients after hospitalization. 


\section{Conclusion}

Patients hospitalized at the Cardiology Department of the Special Hospital for Medical Rehabilitation Krapinske Toplice in lifestyle assessment mostly agree with the statements that before hospitalization they were often tense, angry or worried about the events in the society and the media. Rural participants compared to those from suburban and urban areas, had the most risky lifestyle before hospitalization. Most patients decided to change their lifestyle after hospitalization. The highest degree of decision is related to smoking reduction and initiation of regular physical activity in form of walking more.

Older participants make significantly less decisions about changing their lifestyle after hospitalization. Also, there are no significant differences in the decision of changing lifestyle in terms of gender, work activity and professional occupation. Participants with arrhythmia have a statistically significant higher degree of change compared to those who have myocardial infarction and hypertension. Participants with bypass have statistically significant higher levels of decision about lifestyle changes compared to those who were hospitalized because of arrhythmia. The results are considered to be a significant contributor to the health care of cardiology patients based on evidence.

\section{References}

1. Kralj V, Brkić Biloš I, Ćorić T, Silborčić-Radić M, Šekerija M. Kronične nezarazne bolesti-teret bolesti stanovništva Hrvatske. Cardiologia Croatica. 2015;7-8(10):167175. Croatian.

2. Hrvatski zavod za javno zdravstvo. Svjetski dan srca 2018. Available from: https://www.hzjz.hr/aktualnosti/ svjetski-dan-srca-2018/ Accessed: 20.10.2017. Croatian.

3. World Health Organization. Noncommunicable Diseases Progress Monitor 2017. Available from: https:// www.who.int/nmh/publications/ncd-progress-monitor-2017/en/ Accessed: 20.10.2018.

4. World Health Organization. State of Health in the EU Netherlands Country Health Profile 2017. Available from: http://www.euro.who.int/_data/assets/pdf_fi-
le/0005/355991/Health-Profile-Netherlands-Eng. pdf?ua=1 Accessed: 25.10.2018.

5. Havelka M, Havelka-Meštrović A. Zdravstvena psihologija-Biopsihosocijalne odrednice zdravlja. Zagreb: Zdravstveno veleučilište; 2013. Croatian.

6. Tomljanović N, Jurković N. Prikaz programa zdravstvenog odgoja utemeljenog na modelu „Health Belief Model" Zdravstveni problem: Rak vrata maternice. Hrvatski časopis za javno zdravstvo. 2013;1(35):80-7. Croatian.

7. Maćešić $B$, Špehar B. Prevencija kardiovaskularnih bolesti u primarnoj zdravstvenoj zaštiti. Sestrinski glasnik. 2013;3(18):194-8. Croatian.

8. Emons WH, Meijer RR, Denollet J. Negative affectivity and social inhibition in cardiovascular disease: evaluating type-D personality and its assessment using item response theory. J Psychosom Res. 2007;63(1):27-39.

9. Pluijmers EM, Denollet J. Type $D$ personality as a predictor of poor health outcomes in patients with cardiovascular disease. Neth Heart J. 2017;25(4):286-7.

10. Ghisi GL, Grace SL, Thomas S, Oh P. Behavior determinants among cardiac rehabilitation patients receiving educational interventions: an application of the health action process approach. Patient Educ Couns. 2015;98(5):612-21.

11. Žegura I. Zaštitne i rizične osobine ličnosti za razvoj i tijek koronarne srčane bolesti. Klinička psihologija. 2008;1(1-2):27-36. Croatian.

12. Pogosova N, Saner $H$, Pedersen SS, Cupples ME, McGee $H$, Höfer $S$, et al. Psychosocial aspects in cardiac rehabilitation: From theory to practice. A position paper from the Cardiac Rehabilitation Section of the European Association of Cardiovascular Prevention and Rehabilitation of the European Society of Cardiology. Eur J Prev Cardiol. 2015;22(10):1290-306.

13. Maračić B. Epidemiologija kardiovaskularnih bolesti u Primorsko-goranskoj županiji u razdoblju od 2009.2014. godine. [diplomski rad]. Zagreb: Sveučilište u Zagrebu Medicinski fakultet; 2016. Croatian.

14. Kralj V, Sekulić, Šekerija M. Kardiovaskularne bolesti u Republici Hrvatskoj. Hrvatski zavod za javno zdravstvo. 2013. Croatian.

15. de Hoog N, Bolman C, Berndt N, Kers E, Mudde A, de Vries $\mathrm{H}$, et.al. Smoking cessation in cardiac patients: the influence of action plans, coping plans and self-efficacy on quitting smoking. Health Educ Res. 2016;31(3):350-62.

16. Berndt $N$, de Vries $H$, Lechner L, Van Acker F, Froelicher E.S, Verheugt $F$, et.al. High intensity smoking cessation interventions: Cardiac patients of low socioeconomic status and low intention to quit profit most. Neth Heart J. 2017;25(1):24-32.

17. Bakker EC, Nijkamp MD, Sloot C, Berndt NC, Bolman CA. Intention to abstain from smoking among cardiac rehabilitation patients: the role of attitude, self-efficacy, and craving. J Cardiovasc Nurs. 2015;30(2):172-9.

18. Prugger C, Wellmann J, Heidrich J, De Bacquer D, De Smedt D, De Backer G, et.al. Regular exercise beha- 
viour and intention and symptoms of anxiety and depression in coronary heart disease patients across Europe: Results from the EUROASPIRE III survey. Eur J Prev Cardiol. 2017;24(1):84-91.

19. Žegura I. Psihologija koronarne srčane bolesti. Zagreb: Naklada Slap; 2010. Croatian.

20. Mustajbegović J. Način života i zdravlje. Medicus. 2000; 9(1):7-15. Croatian.

21. Ropac D. Javno zdravstvo. Zagreb: Inter-Ing; 2011. Croatian.

22. Stipešević Rakamarić I. Odabrani pokazatelji i odrednice zdravlja-usporedba urbanih i ruralnih sredina u Varaždinskoj županiji o svjetskom danu zdravlja. Available from: http://www.zzjzzv.hr/?gid=5\&aid=73 Accessed: 02.09. 2017. Croatian.

23. Jones CA, Parker TS, Ahearn M, Mishra AK, Variyam JN. Health status and health care access of farm and rural populations. DIANE Publishing; 2009.
24. World Health Organization. World Health Statistics 2016: Monitoring health for the SDGs. Available from: https://www.who.int/gho/publications/world_health_ statistics/2016/en/ Accessed: 02.09.2017.

25. Soureti A, Hurling R, Murray P, van Mechelen W, Cobain M. Evaluation of a cardiovascular disease risk assessment tool for the promotion of healthier lifestyles. Eur J Cardiovasc Prev Rehabil. 2010;17(5):519-23.

26. Cooper A, Lloyd G, Weinman J, Jackson G. Why patients do not attend cardiac rehabilitation: role of intentions and illness beliefs. Heart. 1999;82(2):234-6.

27. Dohnke B, Nowossadeck E, Müller-Fahrnow W. Motivation and Participation in a Phase III Cardiac Rehabilitation Programme: An Application of the Health Action Process Approach. Research in Sports Medicine. 2010;18(4):219-35.

28. Kralj V. Kardiovaskularne bolesti - veličina problema $i$ mogućnosti prevencije. Cardiologia Croatica. 2012;7(910):231-3. Croatian. 


\section{PROCJENA ODLUKE O PROMJENI ŽIVOTNOG STILA NAKON HOSPITALIZACIJE KOD KARDIOVASKULARNIH BOLESNIKA}

\section{Sažetak}

Svrha istraživanja bila je ispitati životni stil prije hospitalizacije kod kardiovaskularnih pacijenata različitih dijagnoza, kao i spremnost na promjenu životnog stila nakon hospitalizacije. Ti podaci mogu znatno utjecati na rad medicinskih sestara tijekom rehabilitacije i edukacije kardiovaskularnih pacijenata te poticanja motivacije na promjenu rizičnih ponašanja.

Sudionici istraživanja bili su pacijenti kardiološkog odjela Specijalne bolnice za medicinsku rehabilitaciju Krapinske Toplice ( $\mathrm{N}=70)$. U procjeni životnog stila prije hospitalizacije najviše se slažu s tvrdnjama često sam bio/la napet/a, ljut/a ili zabrinut/a zbog događaja u društvu te često sam bio/la napet/a, ljut/a ili zabrinut/a dok pratim medije. Sudionici sa sela u usporedbi sa sudionicima iz gradskih naselja procjenjuju svoj životni stil prije hospitalizacije statistički značajno riskantnijim. Većina pacijenata odlučila je promijeniti životne navike u odnosu na one koje su imali prije hospitalizacije. Najviše se slažu s tvrdnjama koje se odnose na odluku o smanjenom konzumiranju cigareta i više pješačenja. Stariji ispitanici donose značajnp manje odluka o promjeni životnoga stila nakon hospitalizacije, a nema značajnih razlika u odluci o promjeni životnog stila s obzirom na spol, radnu aktivnost i stručnu spremu sudionika. Ispitanici hospitalizirani zbog aritmije imaju statistički značajno viši stupanj odluke o promjeni u usporedbi s ispitanicima s infarktom miokarda i s hipertenzijom. Ispitanici hospitalizirani zbog ugradnje premosnica imaju statistički značajno viši stupanj odluke o promjeni životnog sti- la u usporedbi s ispitanicima hospitaliziranima zbog aritmije. Dobiveni podaci korisni su za prepoznavanje skupina pacijenata kod kojih medicinske sestre moraju uložiti dodatne napore u stvaranju motivacije za promjenu rizičnoga životnog stila.
Ključne riječi: životni stil, kardiovaskularne bolesti, odluka o promjeni, prevencija 